\title{
Surface Runoff Estimation using RS and GIS - A Case Study of Swarnamukhi River, India
}

\author{
Shanmukha Srinivas $\mathbf{G}^{1}$, Satyanarayana Moorthy D V $\mathbf{V}^{2}$, Yaswanth Kumar $\mathbf{Y}^{3}$, Jyothi $\mathbf{P}^{4}$ \\ ${ }^{1}$ Department of Civil Engineering, College of Engineering, Sri Venkateswara University, Tirupati, Andhra Pradesh, India \\ (Corresponding Author) \\ ${ }^{2}$ Department of Civil Engineering, College of Engineering, Sri Venkateswara University, Tirupati, Andhra Pradesh, India \\ ${ }^{3}$ Department of Civil Engineering, Gonampalli Pulla Reddy Engineering College, Kurnool, Andhra Pradesh, India \\ ${ }^{4}$ Water Resources Department, Government of Andhra Pradesh, Tirupati, Andhra Pradesh, India
}

\begin{abstract}
For proper utilization and management of water, as in planning and design of water storage structures, channel improvement, estimation of surface runoff is essential. Geographic Information System (GIS) is specifically designed to merge maps with database and is well suited to work with all stages of hydrological modeling. Present study aims to quantify the hydrological response of the watershed, Konakaluva, a sub watershed of Sawarnamukhi River flowing across Rangampet, Srikalahasthi and drains into Bay of Bengal for different rainfall conditions. Remote sensing and GIS are used to overcome the inconveniences faced while using conventional methods for estimating runoff. In this project, Natural Resources Conservation System - Curve Number model is used for rainfall-runoff estimation using slope, vegetation cover and drainage density of the basin. Runoff depths are computed for average rainfall values. For an average infiltration condition, estimated surface runoff is $24.6 \mathrm{~mm}$ with correlation coefficient between the observed and predicted (modelled) runoffs being 0.78 . This indicates the method is reliable in predicting the surface runoff of the catchment.
\end{abstract}

Keywords: Antecedent Moisture Condition, Hydrological Soil Group, Curve Number, Runoff, Remote Sensing

\section{Introduction}

Rainstorms generate runoff, and its occurrence and quantity are dependent on the characteristics of the rainfall event, i.e. the intensity, duration and distribution. Apart from these rainfall characteristics, there are number of catchment specific factors, which have a direct effect on the occurrence and volume of runoff. This includes soil type, vegetation cover, slope and catchment type. Curve Number (CN) provides an empirical relationship for estimating initial abstraction and runoff as a function of soil type and land use. Rainfall runoff relationship can be visualized by the factors such as initial abstraction (Ia), direct runoff (Q), and actual retention (F). $\mathrm{CN}$ is an index developed by the Natural Resource Conservation Service (NRCS), to represent the potential for storm water runoff within a drainage area. The $\mathrm{CN}$ for a drainage basin is estimated using a combination of land use, soil, and Antecedent Moisture Condition (AMC) (J P Patil et al. 2008) [8]. There are four hydrologic soil groups: A, B, C and D. Group A have high infiltration rates and group D have low infiltration rates. The present work is taken up, in this context, to predict the runoff occurring at a place owing to the precipitation occurring at that location. The accurate assessment of runoff will lead to effective use of water either by way of agriculture, domestic use, industrial use, power generation, etc. and thus the resources can be managed effectively.

Ragan, R. M. and dan Jackson, T. J. (1980) [9] studied over the land cover requirements of the Soil Conservation Service (SCS) model used to develop volume of runoff for hydrograph synthesis in suburban areas were modified to be compatible with Landsat digital data. Curve numbers obtained with these alternate land cover categories compared well with those obtained in published example problems using conventional categories. Synthetic Flood Frequency relationships computed for a test watershed showed that the conventional approach based on aerial photos agreed well with the Landsat-based approach to land cover determination, Asit Kumar Dandapat and Sanat Nalini Sahoo (2019) [1], developed Interface in ArcGIS for surface runoff estimation using curve number techniques was used to estimate the surface runoff by adopting one of the most widely used NRCS-CN techniques and its three derivatives. The results corroborated the finding that the NRCS-CN based surface runoff predictions are very sensitive to the Antecedent Moisture Condition (AMC) of watershed systems.

\subsection{Study Area and Objective}

The sub continent of India lies in South Asia, of which Andhra Pradesh is a state. Chittoor District of Andhra Pradesh is constituted on $1^{\text {st }}$ April, 1911 and the global situation is between $12^{\circ} 37^{\prime}$ to $14^{\circ} 8^{\prime}$ of Northern latitude and $78^{\circ} 33^{\prime}$ to $79^{\circ} 55^{\prime}$ of Eastern longitude (Fig 1). The district is divided in to three revenue divisions i.e. Chittoor, Madanapalle and Tirupati with 66 Mandals covering 1540 Revenue Villages.

The objective is to develop a procedure by which interpreting remotely sensed imagery in hydrologic process can be represented and approximately estimated in a gauged basin. The hypothesis refers to the convenience of the adopted method to estimate the runoff and peak discharge of an area using remote sensing interpretation and GIS and empirical formulae, trying to prove the method applicability for runoff estimations based on indirect measurements. The 


\section{International Journal of Science and Research (IJSR) \\ ISSN: 2319-7064}

ResearchGate Impact Factor (2018): 0.28 | SJIF (2019): 7.583

present study aims to get an approximation to the hydrological response of the landscape unit of the Konakaluva watershed covering an area of 75.37 sq.km.

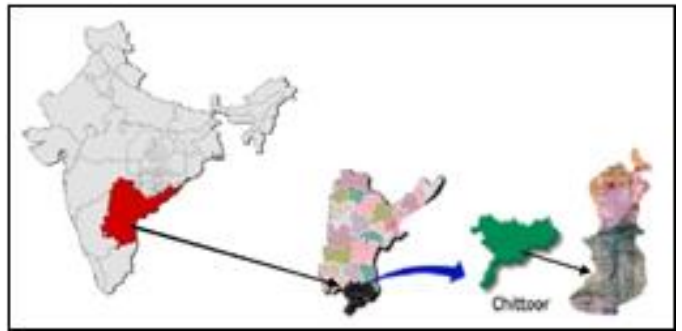

Figure 1: Location of the Study Area

\section{Material and Method}

Many methods for estimating runoff exist. Runoff volume or rate estimation involves estimating the amount of rainfall exceeding infiltration and initial abstractions, which must be satisfied before the occurrence of runoff. Infiltration excess runoff can be estimated using different techniques. Some of the methods like Rational Method, Synthetic unit Hydrograph Method, and coming to the adopted method in the present study is NRCS method. The technique is considered as a reliable one. It has been used for many years as it was adopted as an alternative to the rational and other methods. It can also be considered as computationally efficient. The required inputs are generally available, and it relates runoff to soil type, land use and management practices. The steps involved in the estimation of runoff can be broadly grouped as follows, deciding the AMC, interpretation of satellite imagery, preparation of hydrological soil group map, calculation of potential maximum retention ( $S)$ and calculation of Runoff $\left(\mathrm{Q}_{\bmod }\right)$ for the sub- watershed.

The NRCS (SCS) method (1986) [7] accounts for this possibility by allowing the curve number to depend on AMC in 5 days moisture or wetness condition of the soil before occurrence of a storm. This is determined by the total rainfall in the 5 days period preceding a storm.

NRCS has identified three types of multi-level humidity conditions (antecedent moisture condition) as a factor affecting $\mathrm{CN}$ on land, namely: dry (condition 1, wilting point has not been reached), the mean (condition 2), and saturated water (condition 3). Curve numbers corresponding to AMC-I and AMC-III conditions can be computed from $\mathrm{AMC}-\mathrm{II}$. The computed $\mathrm{CN}$ is rounded to the nearest whole number and the table values represents at AMC II condition used in this study. To determine the value of $\mathrm{CN}$ at AMC I and III, using table obtained by the empirical formulae, $\mathrm{CN}$ I and CN III are:

$$
\begin{aligned}
& C N(I)=\frac{4.2 \mathrm{CN}(\mathrm{II})}{10-0.058 \mathrm{CN}(\mathrm{III})} \\
& C N(I I I)=\frac{23 \mathrm{CN}(\mathrm{II})}{10+0.13 \mathrm{CN}(\mathrm{II})}
\end{aligned}
$$

\subsection{Preparation of Hydrological Soil Group (HSG)}

Soil parameters influence the process of generation of runoff from rainfall and they must be considered in the methods of runoff estimation. The properties of soil which influence the runoff are clay in the surface layer, average clay content in the profile, infiltration, permanent soil texture, Sudhir Kumar Singh and Kishan Singh Rawat (2017) [15]. These soils data are to be determined from actual field investigation or to be obtained from various sources such as soil map prepared by National Bureau of Soil Survey (NBSS), State Agriculture Department. Infiltration rates of soils vary widely and are affected by subsurface permeability as well as surface intake rates. Soils are classified in to four hydrologic groups HSG's (A, B, C, and $\mathrm{D})$, according to their minimum infiltration rate, which is obtained for the bare soil after prolonged wetting. Table 1 gives a brief description of the soil groups.

Table 1: Hydrological Soil Group and textures

\begin{tabular}{|c|c|}
\hline HSG & Soil textures \\
\hline A & Sand, Loamy Sand or sandy loam \\
\hline B & Silt loam or loam \\
\hline C & Sandy clay loam \\
\hline D & Clay loam, silty clay loam, sandy clay, silty clay or clay \\
\hline
\end{tabular}

\subsection{Hydrologic Condition}

The different Hydrological Soil Group in the study area are categorized as shown in Table 2. The hydrologic condition of range land, meadow, or pasture is defined to be 'good' if it is highly grazed and has vegetative cover or more than $75 \%$ of the area. Conversely, a 'poor' hydrologic condition corresponds to a heavily grazed area with vegetation covering less than $50 \%$ of the surface.

Table 2: Area of Hydrological Soil Group

\begin{tabular}{|c|c|c|}
\hline No. & HSG & Area $\left(\mathrm{km}^{2}\right)$ \\
\hline 1 & A & 21.45 \\
\hline 2 & B & 15.77 \\
\hline 3 & C & 16.02 \\
\hline 4 & D & 22.13 \\
\hline \multicolumn{3}{|c|}{ Total } \\
\hline
\end{tabular}

\subsection{Preparation of Soil Cover Complex}

Soil cover complex map is prepared by integrating or overlaying hydrological soil group map and land use map. Polygons formed out this are assigned a curve number considering the average antecedent moisture condition (AMC II). The sub watershed which are having more than one curve number values are identified and assigned a single curve number for each sub watershed by calculating the weighted average of the curve numbers.

\subsection{Assigning Actual Curve Number Values}

From the weighted curve number (AMC II) the curve number of the sub- watershed is reassigned to a modified curve number and using the actual antecedent moisture condition (AMC I - III) of the watershed on daily rainfall basis. In determining the value of $\mathrm{CN}$ should also pay attention to soil moisture conditions prior or antecedent moisture conditions. Water-saturated soils, contributing to generate large surface water and ground with dry conditions contributed little to generate runoff. 


\section{International Journal of Science and Research (IJSR) \\ ISSN: 2319-7064}

ResearchGate Impact Factor (2018): 0.28 | SJIF (2019): 7.583

Table 3: CN Values for different Land Cover and HSG

\begin{tabular}{|c|c|c|c|c|c|}
\hline \multirow{2}{*}{ No. } & \multirow{2}{*}{ Land cover } & \multicolumn{4}{|c|}{ Hydrologic soil group } \\
\cline { 3 - 6 } & & $\mathrm{A}$ & $\mathrm{B}$ & $\mathrm{C}$ & $\mathrm{D}$ \\
\hline 1 & Forest & 25 & 55 & 70 & 77 \\
\hline 2 & Open scrub & 72 & 82 & 88 & 90 \\
\hline 3 & Residential area & 60 & 74 & 83 & 87 \\
\hline 4 & Waste land & 36 & 60 & 73 & 78 \\
\hline 5 & Agriculture & 64 & 75 & 83 & 87 \\
\hline 6 & Water bodies & 98 & 98 & 98 & 98 \\
\hline
\end{tabular}

$\mathrm{CN}=(\%$ Impervious $) *(98)+\{(1-\%$ Impervious $) *(\mathrm{CN}-$ for different hydrologic condition \& and Cover $)\}$
Cover Classification in the use of models to predict the amount of curve number runoff are presented in Table 3. The amount of run-off flow obtained in this study include: Run-off observations (Qobs) and run-off model (Qmod). Runoff and rainfall observations derived from data that is paired with the flow hydrograph. While the run-off model is obtained by the method of Curve Number, as suggested from Ragan, R. M. and dan Jackson, T. J.(1980).

\subsection{SCS Curve Number Model}

NRCS rainfall runoff model (1986) [7], developed by United States Department of Agricultures (USDA) provides an empirical relationship estimating initial abstraction and runoff as function of soil type and land use. The water balance equation is expressed by

$$
\mathrm{Q}=\mathrm{P}-(\mathrm{Ia}+\mathrm{F})
$$

Where $\mathrm{Q}$ is direct runoff, $\mathrm{P}$ is rainfall, Ia is the sum of all losses before the beginning of runoff and $\mathrm{F}$ is retention after runoff begins. Estimation of rainfall runoff using NRCS $\mathrm{CN}$ model is defined by the equation given below

$$
Q=\frac{\left(P-\mathrm{I}_{\mathrm{a}}\right)^{2}}{P-\mathrm{I}_{\mathrm{a}}+\mathrm{S}}
$$

For Indian soil condition, the above relation is modified as,

$$
\mathrm{Ia}=0.2 \mathrm{~S}
$$

Substituting for Ia in the generalized runoff equation produces

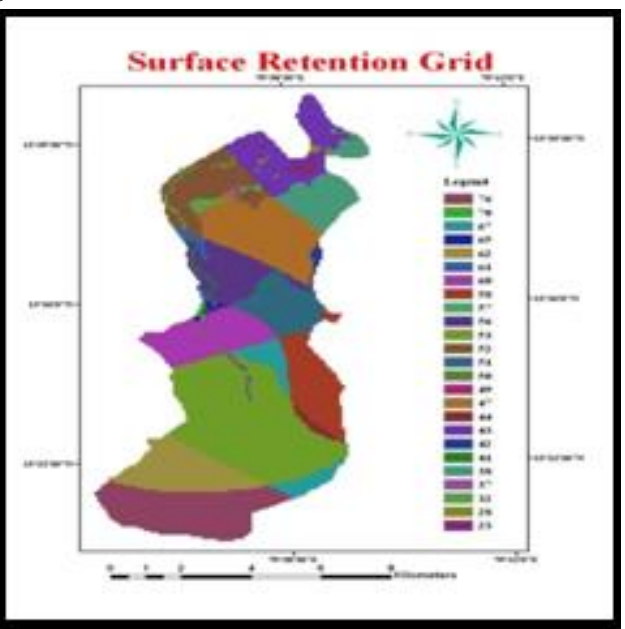

Figure 2: Surface Retention Grid Map

$$
Q=\frac{(P-0.2 \mathrm{~S})^{2}}{P-0.2 \mathrm{~S}+\mathrm{S}}
$$

Where $\mathrm{Q}$ is the runoff given precipitation depth $\mathrm{P}, \mathrm{S}$ is the maximum storage depth, and $\mathrm{CN}$ is the runoff curve number. The Surface Retention Grid and Runoff Grid are derived from GIS environment as shown in Fig. 2 and Fig.3, derived calculations of runoff are shown in the Table 4.

$$
S=\frac{25400}{\mathrm{CN}}-254
$$

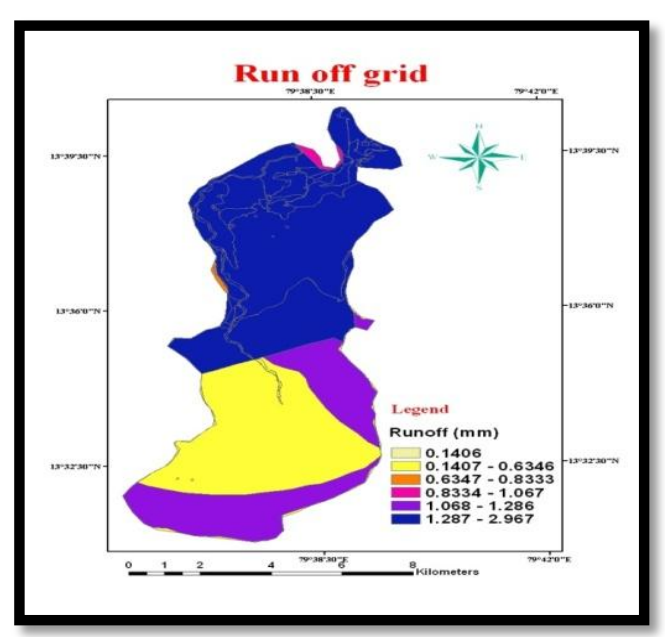

Figure 3: Surface Runoff Grid Map

\section{Results And Discussion}

NRCS - Curve Number method is used in the present study for estimating the quantity of runoff from the gauged Konakaluva watershed. In order to compare and evaluate the accuracy of the results from the NRCS - CN technique, 30 rainfall events are selected during the monsoon period of years 2007 - 2009 and the resulting runoff depths are collected and analyzed. Runoff depths are computed for various given rainfall values, and highest average rainfall was observed in the month of August with a depth of 29.6 $\mathrm{mm}$. For an average infiltration condition the estimated surface runoff is $24.6 \mathrm{~mm}$. Furthermore, correlation between the Qobs and Qmod by using statistical analysis has been included to know the reliability of the method adopted.

Table 4: Calculation of Runoff and observed values for the catchment

\begin{tabular}{|c|c|c|c|c|c|c|c|c|}
\hline Date & $\begin{array}{c}\text { Rainfall } \\
(\mathrm{mm})\end{array}$ & $\begin{array}{c}\text { AMC } \\
(\mathrm{mm})\end{array}$ & $\begin{array}{c}\text { AMC } \\
\text { Class }\end{array}$ & $\mathrm{CN}$ & Ia & $\mathrm{S}$ & $\mathrm{Q}_{\text {model }}$ & Q $_{\text {observed }}$ \\
\hline 1 June, 2007 & 4 & 2.29 & I & 74 & 17.84 & 89.24 & 2.5 & 2.0 \\
\hline 6 June, 2007 & 2 & 24.43 & I & 74 & 17.84 & 89.24 & 3.4 & 2.6 \\
\hline 19 June, 2007 & 21.5 & 102.14 & III & 74 & 17.84 & 89.24 & 0.1 & 0.0 \\
\hline 1 July, 2007 & 8.3 & 325.9 & III & 82 & 11.15 & 55.75 & 0.2 & 0.0 \\
\hline 2 July, 2007 & 22 & 292.1 & III & 82 & 11.15 & 55.75 & 1.8 & 1.1 \\
\hline 5 July, 2007 & 11.7 & 69.6 & III & 82 & 11.15 & 55.75 & 0.0 & 0.0 \\
\hline 10 July, 2007 & 5.9 & 80.8 & III & 82 & 11.15 & 55.75 & 0.5 & 0.2 \\
\hline
\end{tabular}

Volume 9 Issue 5, May 2020 


\section{International Journal of Science and Research (IJSR) \\ ISSN: 2319-7064}

ResearchGate Impact Factor (2018): 0.28 | SJIF (2019): 7.583

\begin{tabular}{|l|c|c|c|c|c|c|c|c|}
\hline 16 July, 2007 & 6.2 & 212.2 & III & 82 & 11.15 & 55.75 & 0.5 & 0.1 \\
\hline 17 July, 2007 & 3 & 190.7 & III & 82 & 11.15 & 55.75 & 1.4 & 1.0 \\
\hline 26 July, 2008 & 1.2 & 104.5 & III & 82 & 11.15 & 55.75 & 2.2 & 1.2 \\
\hline 29 July, 2008 & 9.1 & 103.5 & III & 90 & 5.64 & 28.22 & 0.4 & 0.0 \\
\hline 30 July, 2008 & 3.2 & 81 & III & 90 & 5.64 & 28.22 & 0.2 & 0.0 \\
\hline 15 Aug, 2008 & 47 & 222.7 & III & 90 & 5.64 & 28.22 & 24.6 & 29.6 \\
\hline 16 Aug, 2008 & 4.6 & 204.1 & III & 90 & 5.64 & 28.22 & 0.0 & 0.0 \\
\hline 17 Aug, 2008 & 4.4 & 198.7 & III & 90 & 5.64 & 28.22 & 0.1 & 0.0 \\
\hline 18 Aug, 2008 & 10.2 & 55.4 & III & 90 & 5.64 & 28.22 & 0.6 & 0.2 \\
\hline 22 Aug, 2009 & 63 & 40.3 & II & 83 & 10.40 & 52.02 & 26.4 & 33.5 \\
\hline 23 Aug, 2009 & 3.2 & 41.3 & II & 83 & 10.40 & 52.02 & 1.2 & 1.6 \\
\hline 26 Aug, 2009 & 8 & 41.1 & II & 83 & 10.40 & 52.02 & 0.1 & 0.9 \\
\hline 27 Aug, 2009 & 1.8 & 42.6 & II & 83 & 10.40 & 52.02 & 1.7 & 4.1 \\
\hline 1 Sep, 2009 & 4.2 & 21.8 & I & 74 & 17.84 & 89.24 & 2.5 & 2.9 \\
\hline 4 Sep,2009 & 2 & 10.5 & I & 74 & 17.84 & 89.24 & 3.4 & 6.0 \\
\hline 14 Sep,2009 & 4.8 & 145.6 & III & 90 & 5.64 & 28.22 & 0.0 & 0.0 \\
\hline 16 Sep,2009 & 2 & 105.8 & III & 90 & 5.64 & 28.22 & 0.5 & 0.0 \\
\hline 20 Sep,2009 & 2.6 & 23.2 & I & 74 & 17.84 & 89.24 & 3.1 & 5.8 \\
\hline
\end{tabular}

\subsection{Statistical Analysis}

The runoff from the model i.e. $\mathrm{Q}_{\bmod }$ is compared with the observed runoff, $\mathrm{Q}_{\mathrm{obs}}$ with a simple statistical analysis. The statistical data obtained from the model predicted and observed data has been obtained from each individual period for three years from $2007-2009$, correlation is evaluated. The correlation for the year 2007 has a high value showing the method applicability by this method is reliable, and a slight decrease and increase in 2008 with $r=0.70$ and in 2009 with $\mathrm{r}=0.75$ respectively, shows good level of accuracy. The correlation for the periods $2007-2009$ has correlated with $r=0.78$, showing the results that runoff estimation using NRCS - Curve Number method is quite good and provide us a simple method of application and cost effective.

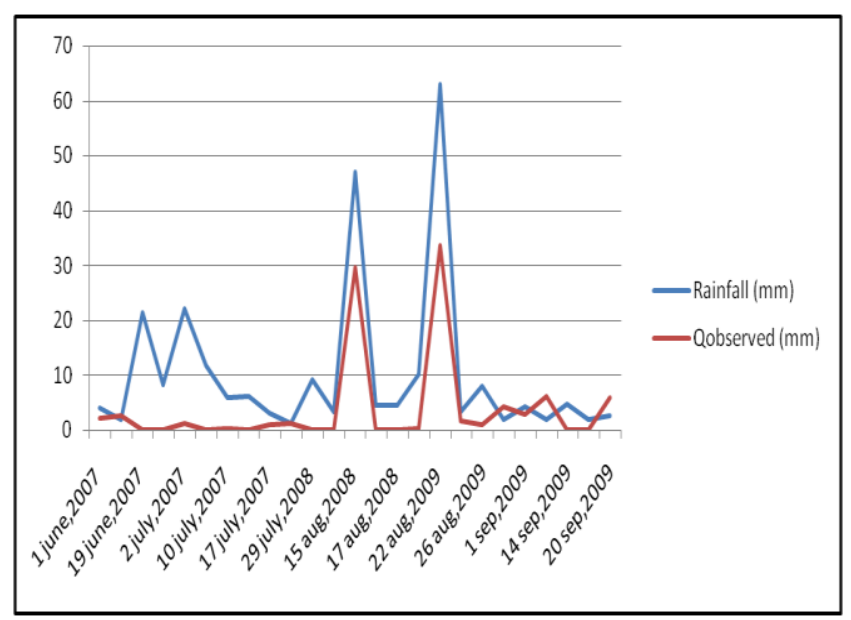

Figure 4: Variation of Rainfall and Observed Runoff

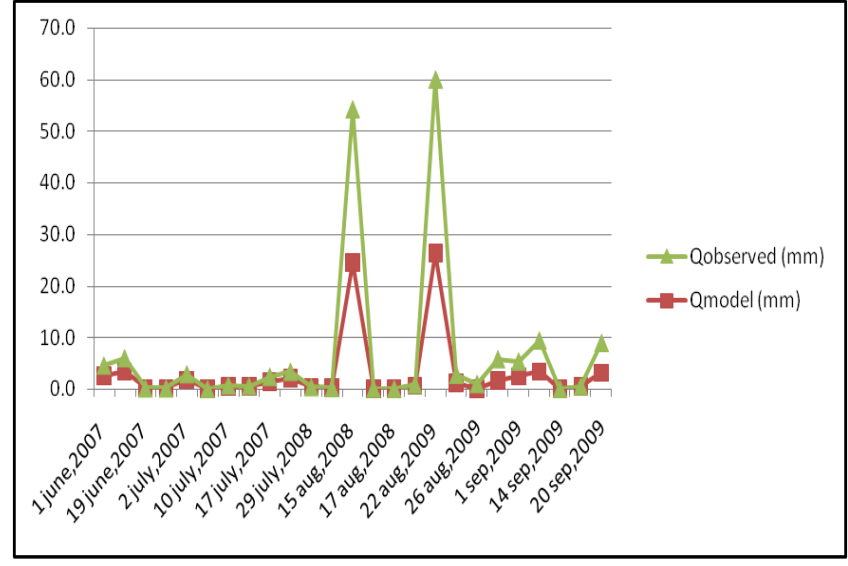

Figure 5: Variation of Model and Observed Runoff

The results predicted by this method is good enough to estimate the amount of runoff caused by rainfall in the watershed. Fig. 4 and Fig.5 shows the variations of rainfall and observed runoff after initial abstraction and comparison between model predicted and observed runoff following a rhythm fluctuation are well concentrated which shows the reliability of NRCS - Curve Number Method.

The correlation coefficient between the predicted and observed runoff shows a high value $(\mathrm{r}=0.78)$ indicating the method is reliable in predicting the surface runoff of the catchment which is shown in Table 5.

Table 5: Correlation between Runoff Model and Observed values

\begin{tabular}{|c|c|c|}
\hline Year & No. of values (n) & Correlation (r) \\
\hline 2007 & 9 & 0.91 \\
\hline 2008 & 7 & 0.70 \\
\hline 2009 & 9 & 0.75 \\
\hline $2007-2009$ & 25 & 0.78 \\
\hline
\end{tabular}

\section{Conclusion}

It was observed by analyzing the rainfall data in the study area is more concentrated in monsoon season only. The changes in Land Cover and AMC affect the value of Curve Number and they in turn influence Surface Runoff. The

Volume 9 Issue 5, May 2020 www.ijsr.net 


\section{International Journal of Science and Research (IJSR) \\ ISSN: 2319-7064}

ResearchGate Impact Factor (2018): 0.28 | SJIF (2019): 7.583

model performs very well in fairly saturated soil conditions or high soil moisture. In conclusion, the NRCS - $\mathrm{CN}$ method gives better prediction on surface runoff from the basin in fairly saturated soils.

\section{References}

[1] Asit Kumar Dandapat and Sanat Nalini Sahoo (2019) Evaluation of loss models and effect of LU/LC changes on surface runoff in Subarnarekha river basin, ISH Journal of Hydraulic Engineering, DOI: 10.1080/09715010.2019.1619489

[2] Bondelid, T.R., Jackson, T.J., dan McCuen, R.H., (1982). Estimating runoff curve numbers using remote sensing data. Proceedings of the International Symposium on Rainfall - Runoff Modeling. Applied Modeling in Catchment Hydrology, Water Resources Publications, Littleton, CO, hal. 519-528.

[3] C.Chatterjee M. ISH, R. Jha, A. K. Lohani M. ISH, Rakesh Kumar \& R. Singh (2002) Estimation Of SCS Curve Numbers for a Basin Using Rainfall-Runoff Data, ISH Journal of Hydraulic Engineering, 8:1, 4049, DOI: $10.1080 / 09715010.2002 .10514705$

[4] Griend, H.A., (1979). Modelling catchment Response and Runoff Analysis, Ins. Of Earth Sciences FreeUniversity, Amsterdam, The Netherlands.

[5] Jain, S. K., (1996) GIS for Estimation of Direct Runoff Potential, Journal of Water Resources, 2 (1), pp 42-47.

[6] Nachabe, M.H., (2006). "Equivalence between TOPMODEL and the NRCS Curve Number Method in Predicting Runoff Source Areas", Journal of the American Water Resources Association (JAWRA), Vol. 42, No. 1, hal. 225-235.

[7] Natural Resources Conservation Service Conservation Engineering Division, (1986). Urban Hydrology for Small Watersheds, Technical Release 55, United States Department of Agriculture.

[8] Patil, J.P., Sarangi, A., Singh, A.K., and Ahmad, T. (2008), "Evaluation of modified $\mathrm{CN}$ methods for watershed runoff estimation using a GIS-based interface", Bio systems Engineering, ElsevierISSN: 1537-5110; vol 100 (2008) 137-146

[9] Ragan, R. M., dan Jackson, T. J., (1980). Runoff synthesis using Landsat and the SCS model, J. Hydraul. Div. ASCE, Vol. 106, hal. 3-14.

[10] R.K. Sahu, S.K. Mishra and T.I. Eldho (2012) Performance evaluation of modified versions of SCS curve number method for two watersheds of Maharashtra, India, ISH Journal of Hydraulic Engineering, 18:1, 27-36, DOI: $10.1080 / 09715010.2012 .662425$

[11] S. Satheeshkumar, S. Venkateswaran, R. Kannan, (2017). Rainfall-runoff estimation using SCS-CN and GIS approach in the Pappiredipatti watershed of the Vaniyar sub basin, South India, Model Earth Systems and Environment, Springer publication: ISSN23636203.

[12] S. Vidyavathi M. ISH (2007) An integrated approach for the assessment of water availability in a Watershed, ISH Journal of Hydraulic Engineering, 13:1, 56-76.

[13] Sanat Nalini Sahoo and P. Sreeja (2013) Role of rainfall events and imperviousness parameters on urban runoff modelling, ISH Journal of Hydraulic Engineering, 19:3, 329-334

[14] Slack, R. B., dan Welch, R., (1980). Soil conservation service runoff curve number estimates from Lands at data, Bull. Wat. Resour. Vol. 16, hal 887-893.

[15] Sudhir Kumar Singh and Kishan Singh Rawat, (2017). Estimation of Surface Runoff from Semi-arid Ungauged Agricultural Watershed Using SCS-CN Method and Earth Observation Data Sets, Water Conservation Science Engineering, Springer publication; ISSN2366-3340.

\section{Author Profile}

Shanmukha Srinivas Gorantla

ORCID: https://orcid.org/0000-0002-2039-898X 